\title{
A Triangle of Regrets: Training of Ottoman Children in Germany During the First World War
}

\author{
Nazan Maksudyan
}

In Sabahattin Ali's famous novel Kürk Mantolu Madonna [Madonna in a Fur Coat], Raif Efendi, a relatively young boy, is sent to Germany to learn the trade of soap manufacturing in order to take over his father's business and run it with more technological and up-to-date methods. However, he does not have the slightest ambition or eagerness to accomplish what is asked from him. Instead, he shows more interest in the German language and culture than his work in the factory. He lives in a pension that houses a colorful mixture of international guests and learns German from an army officer. In fact, he spends a long time in the 'learning the language' phase, which finally turns out to be the last step in his German education, due to an unexpected love affair with the portrait of a melancholy young woman. After seeing the painting of Maria Puder for the first time in an opening, he is virtually struck down and instantly bewitched by the woman and starts going to the gallery every day. He is so deeply absorbed in the picture that when one day the painter of the self-portrait approaches to him, he could not recognize her. Set in 1920s Berlin with its nightclubs, restaurants, the Romanisches Café and other legendary sites, the story spans six months, almost reaching to a happy ending but then breaking off abruptly.

Sabahattin Ali's genius in constructing an exceptional love story and in penetrating deep into the inner lives of his protagonists is singular. Yet, the sergüzeşt [adventure] of Raif Efendi in Germany is actually not so exceptional in the context of the sending of Ottoman youngsters to Germany for vocational education and training during the First World War. Although constantly blamed by both disillusioned home and host countries as lazy, disobedient and unprepared, etc., Ottoman vocational students and apprentices in Germany felt the most betrayed and discontented with their lot, with their hopes of leading more prosperous lives in Germany shattered. My paper concentrates on the experiences of this earliest and youngest generation of Turkish/Ottoman migrant workers in Germany. As destitute and rootless lads, these children, collected from orphanages, were not only practically expelled from their home country, but in their migrant worker situation also suffered poverty, exclusion and disconnection. This paper explores their accounts of discomfort and 
unhappiness during their stay. As a twist to this grey story, which offers little hope for a happy ending, in the final section of the paper I give a relatively more detailed and individual account of the experiences of two Ottoman orphan boys, an apprentice and a high school student, who decided to stay in Germany long after the organized return trips in 1919. Arguably, they found a better environment for their education and life prospects and also felt integrated enough to settle in Germany, despite the official call (and arrangements) for their return.

\section{Educational Collaborations between the German Kaiserreich and the Ottoman Empire}

The turcophile journalist Ernst Jäckh founded the Deutsch-Türkische Vereinigung [DTV, German-Turkish Association] in 1912, initially to bring together financial and industrial corporations with interests in the eastern Mediterranean. ${ }^{1}$ These corporations made substantial donations to the DTV in support of its declared aim of cultural rapprochement, including guided tours in Germany for Ottoman politicians and businessmen to impress them with the country's achievements, and educational initiatives in the Ottoman Empire. More importantly, the DTV built organic links with the German Foreign Office, such that it had tight control over the implementation of foreign policy towards the Ottoman Empire. The DTV would use the considerable funds at its disposal in coordination with the Foreign Office for expenses exceeding the latter's budget. Hans von Wangenheim, the German ambassador in Istanbul from 1912 onwards, pushed for a closer alliance under Jäckh's guidance and through his friendship with Enver Pasha, an enthusiastic admirer of Germany. ${ }^{2}$

At Jäckh's initiation, an Ottoman delegation of fifteen prominent men, consisting of politicians, businessmen, army officers, administrators, agriculturists and a journalist, was invited to Germany in 1911. Financially, the project was funded by the German Foreign Ministry through a German consortium of banks. The guests traveling from Istanbul arrived in Berlin on June 18, 1911. Their 27-day visit includes the cities of Preußen, Sachsen, Württemberg, Bayern, Hamburg

1 The full name of the society is given in the earlier correspondence.

2 Malte Fuhrmann, "Germany's Adventures in the Orient: A History of Ambivalent Semicolonial Entanglements," in Max Langbehn Volker and Mohammad Salama (eds), German Colonialism: Race, the Holocaust, and Postwar Germany (New York: Columbia University Press, 2011), $123-145$. 
and Bremen, and they saw the landmarks of German industry, especially that of arms industry. When they were finally back in Berlin, they were presented with evidence of German progress in municipal enterprises such as hospitals, fire departments, tramways, slaughterhouses, waterworks and open-air swimming pools. $^{3}$ One of the participants in the tour was the Ottoman undersecretary of state, Edhem Bey, and he decided to send technicians, apprentices and vocational school students to German factories for training - instead of to French ones. Up until 1914, just 24 technicians from the Ottoman Empire had received training by working in German factories, and a few others had come to Germany to study at university. ${ }^{4}$ The new increase in the supporters and idealizers of Germany-rather than France-meant adopting an entirely different educational philosophy and role model. From the rise of the Committee of Union and Progress to power onwards, Ottoman educational journals were filled with articles on German education, economics and industry, and admiration for Germany frequently underlined German proficiency in technical education.

Once the Ottomans entered the war, the German Military Supreme Command and Foreign Office pursued good relations with the Ottoman government and sought to build channels of German cultural influence. Educational and cultural collaboration gained ground, and a German official was appointed to a key position in almost every ministry. Dr Franz Schmidt, a former inspector of German schools abroad, became the German advisor to the Ministry of Education and worked out a new law on basic education. He devised a large-scale reform program, altering the curricula, appointing German teachers and professors, and introducing instruction in German language in schools. Teacher training seminars were organized, and a number of aspiring teachers were sent to seminars in the Reich. German teachers started to teach in certain elite high schools and in vocational schools in Anatolia. Twenty German professors were appointed to Istanbul University, both to teach and contribute to its reform. ${ }^{5}$

Ottoman entry into the war also changed the direction and extent youth transfer to Germany. Pupils and orphan apprentices, together with workers and university students were sent to Germany in much higher numbers and as a systematic Young Turk project. It was a mutual project for both countries: on

3 Fünfzig offizielle Gäste, "Die Studienreise der osmanischen Delegation - ein Meilenstein in den deutsch-türkischen Beziehungen." In Ingeborg Böer, Ruth Haerkötter and Petra Kappert (eds), Türken in Berlin 1871-1945: eine Metropole in den Erinnerungen osmanischer und türkischer Zeitungen (Berlin: de Gruyter, 2002), 107-116.

4 Mustafa Gencer, Nationale Bildungspolitik, Modernisierung und kulturelle Interaktion: Deutsch-türkische Beziehungen (1908-1918) (Münster: LiT, 2002), 265.

5 Fuhrmann, "Germany's Adventure," 135. 
the Turkish side powerful Young Turks such as Talat Paşa, Enver Paşa and Dr Nazım Bey were in charge, while important figures on the German side Paul Rohrbach, Jäckh, Hjalmar Schacht and Franz Schmidt. The DTV played a leading role in negotiations, as well as in organizing and carrying out the plan, as did the Türkische-Deutschen Vereinigung [TDV, Turkish-German Association in Istanbul]. Both groups hoped to achieve effective mutual rapprochement through the direct contact of large numbers of Ottoman boys with German language and culture though this one-way 'exchange' program; already by the beginning of the war, 2,00o young people had been sent to study in German schools and to be trained in German companies.

The idea of sending Ottoman orphan boys to work as apprentices in German handicrafts, mines and farms during the First World War belonged to Enver Pasha, Minister of War and the leading figure of the CuP. In late 1916, Enver Pasha informed the German military plenipotentiary in Constantinople that the government was willing to send many more boys $(5,000-10,000)$ aged between 12 and 18 years to Germany. They would be apprentices in all types of crafts, agriculture - including forestry and dairy farming — and mining. ${ }^{6}$ Since this education and training of Ottoman boys was entirely free of cost for the Ottoman government, they were willing to send as many as they could. ${ }^{7}$ The DTV, personified by Jäckh, Dr Hans Hermann Russack and Dr Gerhard Ryll decided to test the idea with several hundred boys: 300 handicraft apprentices, 200 mining trainees and 200 agricultural apprentices were sent in the course of 1917 and 1918. Although there were negotiations for sending girls as well, the project did not continue long enough for the fulfilment of this phase, and the displacement comprised only of boys.

6 Gencer, Nationale Bildungspolitik, 268-269.

7 "Die Ausbildung der Handwerks — und Bergwerkslehrlinge erfolgt für die Türkei ganz kostenlos durch das deutsche Handwerk und den deutschen Bergbau.," in“Tätigkeitsbericht der DTV (für das Jahr 1917)," Auswärtiges Amt Archives, R63454.

The DTV argued that this was thanks to German crafts and mines, but actually it was mostly thanks to the labor of the boys themselves.

Even the education of pupils and students ended up accruing no debt to the Ottoman treasury. The annual cost for the education of the Ottoman students would amount to $500,000 \mathrm{Mks}$, half of which was to be paid by parents and the other half covered by the German side. For 1916/1917 the Kaiser gave 100,00o Mk, German industry gave 40,000 Mk, city councils as a whole gave $100,000 \mathrm{Mk}$, and private donors gave $60,000 \mathrm{Mk}$, so that in the end around 225 students would be able to come for free. Consequently the German side covered $42 \%$ of the costs, while the remaining $58 \%$ came from the parents. "Tätigkeitsbericht der DTV (für das Jahr 1917)," Auswärtiges Amt Archives, R63454. 


\section{Ottoman Children and Youths in the First World War}

Mass mobilization left the overwhelming majority of Ottoman children unschooled during the war years. ${ }^{8}$ The government first closed almost all foreign schools, including Catholic and Protestant missionary schools. Only German schools, along with some American and Alliance Israelite schools were allowed to remain open. Many private schools were also discontinued, as the War Ministry refused to postpone private school teachers' induction into military service. Being deprived of schooling raised the middle-class concern that children were over-socialized with street life and developing delinquent behaviour; though a significant number of children and youths between the ages of eight and 16 were employed in agriculture, manufacturing and shopkeeping, Ottoman authorities developed a critical discourse on unschooled city children. The Minister of Public Education, Ahmet Şükrü Bey, claimed that the opening of state kindergartens for the first time in 1915 would rescue thousands of children from the socialization of the streets [sokak terbiyesi]. ${ }^{9}$

Innumerable children, whether unschooled or employed, from the city or the country, rich or poor, shared the experience of orphanhood. Hundreds of thousands of children lost their fathers and providers to the war. First of all, the number of Armenian orphans of the Genocide reached hundreds of thousands, probably around 400,000. Based on a report prepared by the Children's Protection Society [Himaye-i Etfal Cemiyeti] after the war, there were 200,000 orphans of martyrs in the country. ${ }^{10}$ By mid-1917 the large network of state orphanages [Darüleytam] opened due to the force of circumstances caused by the war, and also thanks to the confiscation of educational and philanthropic institutions of the Entente Powers (mostly run by missionaries) — was providing for almost 11,000 orphans. ${ }^{11}$

8 For further information on children and youths in the Ottoman Empire during war years, see Nazan Maksudyan, "Children and Youth (Ottoman Empire)," in Ute Daniel, Peter Gatrell, Oliver Janz, Heather Jones, Jennifer Keene, Alan Kramer and Bill Nasson (eds), 1914-1918-online: International Encyclopedia of the First World War (Berlin: Freie Universität Berlin, 2015), http://dx.doi.org/10.15463/ie1418.10595.

Benjamin C. Fortna, "The Kindergarten in the Ottoman Empire and the Turkish Republic," in Roberta Lyn Wollons (ed.) Kindergartens and Cultures: The Global Diffusion of an Idea (New Haven: Yale University Press, 2000), 251-273.

Grand National Assembly, Minutes of the 2nd Parliament, 1st Legislative Year (August 11, 1923-Febraury 28, 1924), 15th Session (September 8, 1398 [1923]) [hereafter твмм zC], 469. Available online: http://www.tbmm.gov.tr/tutanaklar/TUTANAK/TBMM/do2/coo1/ tbmm02001015.pdf.

11 The table prepared by the Directorate in mid-1917 gives the exact numbers in all orphanages: BOA, MF.EYT, 7/51, 1/Tm/1333 (September 1, 1917). 
This figure of 11,000 suggests that Enver was thinking of emptying the orphanages by sending all the orphans to Germany. This is understandable, given the difficulty of sheltering, feeding and educating so many orphaned children and youths, and the organizational and financial problems of these institutions. First of all, they were overfilled: the Ottoman archives are full of petitions from district officials or relatives for the admission of such-and-such a child to an orphanage, whose administrators repeatedly declined due to not having any vacancies. ${ }^{12}$ Moreover, the budgets allocated to the orphanage administration constantly proved to be inadequate to cover the expenditures. ${ }^{13}$

From the children's side, it is not difficult to imagine why so many orphans volunteered to be sent away to the unknown. Orphanages were incredibly crowded, and many of them housed more than a thousand boys. Dormitories were neither warm nor comfortable: three to six children were allocated to the same sheetless and pillowless bed, ${ }^{14}$ although they usually lay on the floor, getting closer for warmth. ${ }^{15}$ The proximity of the children also facilitated the spread of disease, as it was impossible to separate the sick from the healthy. ${ }^{16}$ Hygiene was a huge problem: most of the buildings did not have their own water sources, toilets were in a terrible condition, and children had to be taken to the public baths [hamam]. ${ }^{17}$ Moreover, the orphanage administrations could not provide spare clean underwear, and so children had to wear the same items for a long time. These problems regarding cleanliness easily translated into widespread outbreaks of scabies and rashes. ${ }^{18}$ Hunger was the greatest suffering of the orphans: they were consistently underfed with a diet of soups low in nutrition and lacking carbohydrate and protein. Orphan memoirs are full of sad descriptions of never-ending hunger. ${ }^{19}$

\footnotetext{
12 For example, воА, мғ.мкт., 1215/63, 04/B /1334 (May 7, 1916); воА, DH. кмS., 38/3, 29/ Ca/1334 (April 3, 1916); воА, мF.MKT., 1229/46, 24/Za/1335 (September 12, 1917).

13 воА, İ.ммS., 198/1333-N-10, 06/N/1333 (July 19, 1915); воА, İ.MLU., 10/1334-S-34, 24/S/1334 (January 1, 1916); BOA, MF.MKT., 1227/20, 19/Ş /1335 (June 9, 1917).

твмм ZC, 461; воА, MF. ЕҮт., 6/131 (report) cited in Safiye Kiranlar and Aynur Soydan Erdemir, "Köyün Modernleştirilmesine Dair Bir Uygulama ve Proje: Kimsesiz Köy Çocuklarının Köyde Eğitimi," Yakın Dönem Türkiye Araştırmaları, 8, 2005, 94-113. Hasan İzzettin Dinamo, Öksüz Musa (Istanbul: Heyamola Yayınları, 2005), 14-16.

16 твмм ZC, 448-479.

17 вOA, MF. EYT., 6/131 (report) cited in Kıranlar and Erdemir, "Köyün Modernleştirilmesine" 98-99.

18 Dinamo, Öksüz Musa, 18-20.

19 Nissim M. Benezra, Une Enfance Juive à Istanbul, 1911-1929 (Istanbul: Isis, 1996).
} 
It was in this context that German master craftsmen and mine-owners appeared as an option for providing for the orphans. Although they were not properly informed about this foreign land, many orphans applied to go to Germany in 1917, assuming that they would live in better conditions. It is clear from the reports of the DTV that a substantial number of orphans assumed that they would become factory workers and earn a good salary. ${ }^{20}$ What awaited them in Germany was quite different.

\section{War Orphans on Military Trains}

In February 1917 the German Chambers of Trade and Industry agreed to arrange accommodation and work for apprentices, and the project finally got underway. The selection committee, made up of Jäckh, representatives of the Ottoman Ministry of Education and Orphanage Administration, easily rounded up the first group of craft apprentices on the basis voluntary application. They were all declared to be 'orphans of martyrs' chosen from Istanbul orphanages. They were between 14 to 16 years old, with the exception of an orphan named Ibrahim, who was only 7 years old. ${ }^{21}$ The Orphanage Administration prepared special passports for orphans going to Germany (Figure 6.1). ${ }^{22}$ In addition to detailed personal information relating to age, family and physical description, these passports also had comments pages to be filled in by the masters in every three months. ${ }^{23}$ In a sense, passports would make it possible to follow orphans' vocational and educational development in Germany. ${ }^{24}$

The first group of 314 boys departed from Sirkeci Train Station in Istanbul in April 1917. The Balkanzug [Balkan Sürat Katar1] train, which covered the distance between Istanbul and Berlin in only three days, was rejected as an option in order to keep the expenses of the transfer to a minimum. ${ }^{25}$ Instead, the boys had to spend ten days in a military freight train without warm clothes and

20 Dr. Hans Hermann Russack, "Die türkische Lehrlinge," in Türkische Jugend in Deutschland: Jahresbericht der Schülerabteilung der Deutsch-Türkischen Vereinigung (Berlin: DeutschTürkische Vereinigung e.V., 1918), 6 o.

21 "Türkische Jugend in Berlin," Berliner Tageblatt, 216, May 6, 1917.

22 There is a copy of the passport of Mehmet, the son of Yusuf Efendi, in the Ottoman Archives: BOA, MF. EYT, 2/117, 8/Hz/1332 (June 21, 1916).

23 Hakan Aytekin, "1914-1924 Yllları arasında Korunmaya Muhtaç Çocuklar ve Eğitimleri, Marmara Üniversitesi, Türkiyat Enstitüsü” (Unpublished MA Thesis, 2006), 108-110.

24 Nurdan Şafak, “Darüleytam'da Çocuk Olmak: On Çocuk On Portre," FS İ İmi Araştırmalar Insan ve Toplum Bilimleri Dergisi, 2, 2013, 261-284.

25 Russack, "Die türkische Lehrlinge." 


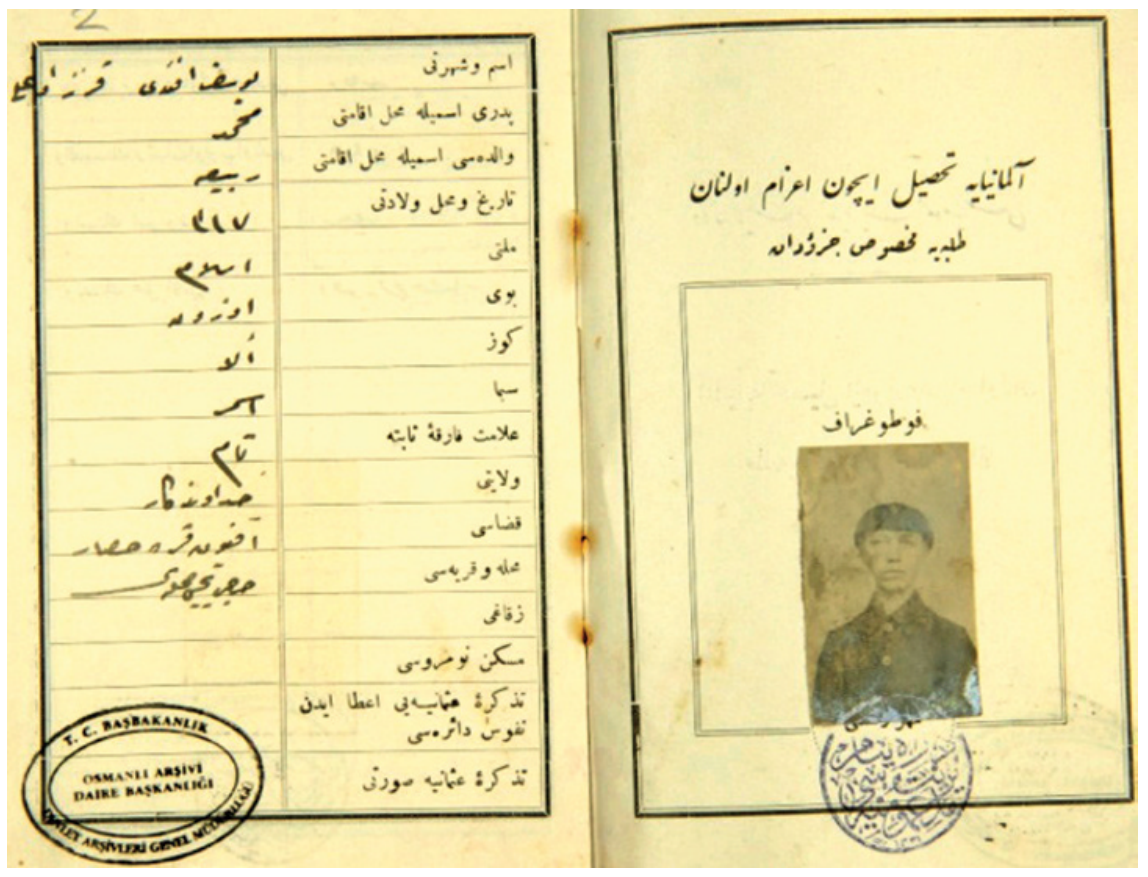

FIGURE 6.1 Passport photo of an orphan sent to Germany in 1917.

barefoot. This partially explains why so many of them were sent back after a few months: they had lung diseases.

Before departing for their various work places, they were housed in one of the city council's quarters in Sophienstraße 34. Soon after their arrival, they were gathered in the courtyard of the community school [Grundschule] at Koppenplatz and were greeted by Major Ramsen from the Ministry of War, the Privy councillors [Geheimräten] Cleff and Göhmann from the Board of Trade [Handelsministerium], Dr Glock from Ministry of Agriculture and Vice-Consul Tahir Bey from the Ottoman Embassy. They were all clothed in the European style, with a blue pelerine as a coat and a blue fez-like cap on the head. Their beautiful photograph on the way to this greeting ceremony featured in Berliner Tageblatt (Figure 6.2) ${ }^{26}$ From Berlin, the boys were sent by the DTV to their posts in Augsburg, Breslau, Bromberg, Dusseldorf, Frankfurt an der Oder, Mannheim, Oldenburg, Schwerin, Weimar and Ulm. The master craftsmen and the Chambers of Trade and Industry committed themselves to pay for the boys' boarding expenses, but not for the cost of their return journey. ${ }^{27}$

26 "Türkische Jugend in Berlin."

27 This should be paid either by the Ottoman government or the boys themselves. 


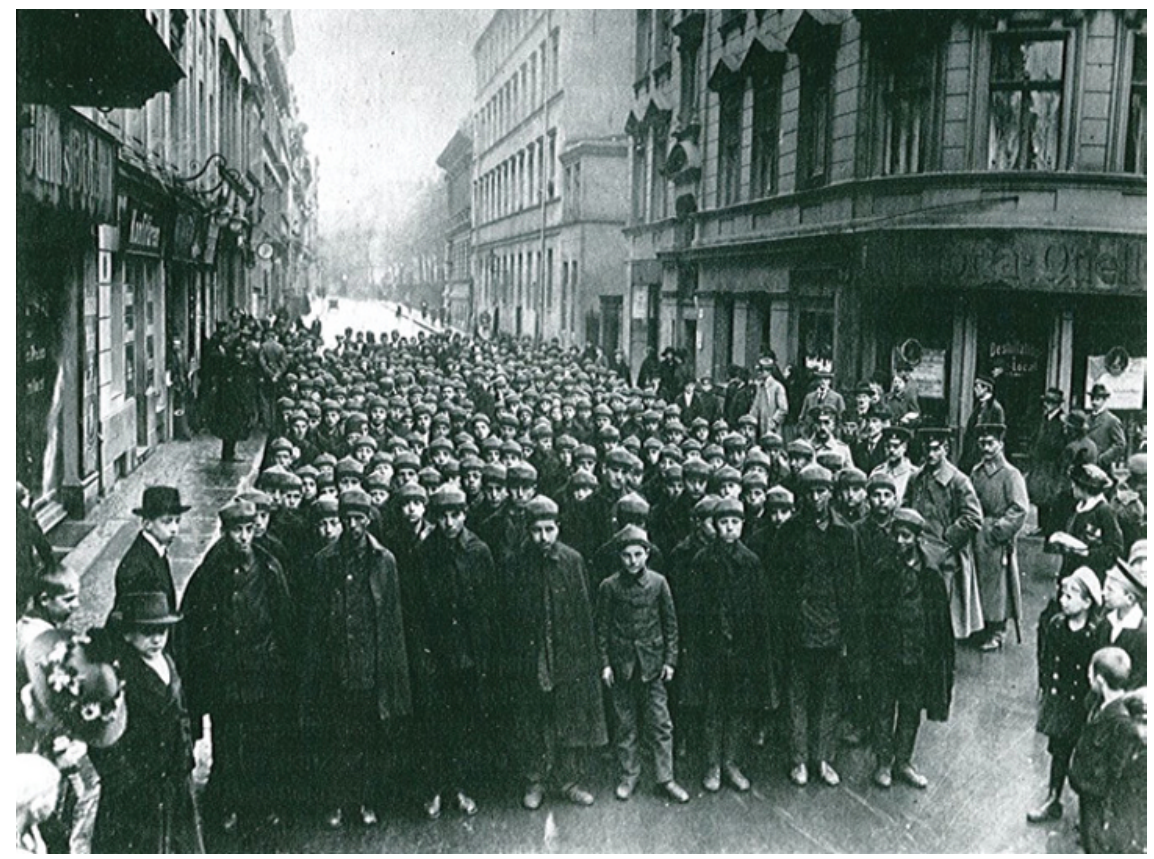

FIGURE 6.2 Photograph of Ottoman craft apprentices in Berlin, May 1917.

In June 1917 a second group of 200 Ottoman boys arrived to be apprenticed in mining areas. ${ }^{28}$ In contrast to the first group, who came from orphanages in Istanbul, this time the boys had been chosen from orphanages in the provinces-from Maraş, Antep, Kilis, Ankara, Söğüd, Niğde, Konya, Bursa, Manisa and Karahisar, and from the CUP orphanage in Edirne. The boys from the eastern provinces had to make a 30-day journey: 20 days on the Anatolian railway before the 10 days on the military train from Istanbul to Berlin. In Berlin, the group has housed in the rooms of Gustavo's Inn [Gastwirtes Gustavos] in Hasenheide 52/53. As in the case of first transport, a greeting ceremony was considered and Dr Söhring of the Foreign Office was invited by $\mathrm{Dr}$ Russack of the DTV to visit the boys on the occasion of their distribution to various mines. ${ }^{29}$ Yet, there is no evidence that he actually visited the boys. Based on the plan prepared by the Ministry of Trade and Industry [Ministerium für Handel und Gewerbe] representatives of the various mine administrations

\footnotetext{
28 "From die DTv to Dr. Söhring, Auswärtiges Amt, 13.Juni.1917, Berlin," Auswärtiges Amt Archives, R63063. 
brought them from Berlin to their mining districts. They were about equally divided between the Rhenish-Westphalian mines in the area of Dortmund and Bonn, and those of Saarbrücken and the central German mining areas in the districts of Halle and Clausthal. A small portion was sent to the Wroclaw Mining Administration in Upper Silesia. Most of the boys worked in metal-ore mining (iron, zinc, lead, copper) and the coal industry, and a small number were employed in lignite and cement manufacturing. ${ }^{30}$

Sending the last group, the agricultural apprentices, took much longer than expected. Already in May 1917 approximately 500 agricultural positions were made available for Ottoman boys via a memorandum sent by the DTV to the German Chamber of Agriculture. The boys were to be dispatched from two different centers: those to be placed in the southwest were to arrive at Karlsruhe, and those heading northeast would arrive in Berlin. However, state affairs were moving slower on Ottoman soil. A large number of boys had been brought to Istanbul from the provinces, yet they had to wait idly in already crowded Istanbul orphanages for the preparations to be finalized..$^{31}$ One problem was that travel permits for those born in 1315 and 1316 (i.e. 1897-1899) could not be received from the Ministry of War until October. ${ }^{32}$ During these few months they spent in Istanbul, the behavior of the boys from the provinces was criticized by the directors as inappropriate and spoiled. The administrators raised their concern for the manners of Istanbul orphans, who might be negatively influenced by these village boys. They insisted on the immediate transfer of the boys to Germany. ${ }^{33}$

In the autumn of 1917, the Ottoman Ministry of Education, again in collaboration with the Orphanage Administration, conducted the selection of the boys and sent the list to Germany. However, the DTV officers in Berlin objected to the selection, underlining that only about 100 boys out of the 500 had a rural background. ${ }^{34}$ In response to the demands of the DTV administrators, Dr Nazım, a prominent figure in the CUP central committee and a member of the TDV, promised to organize a new selection and send a large number of agricultural apprentices from among Anatolian "farmer's sons"

$30 \quad$ Russack, "Die türkische Lehrlinge," 54.

31 вОА, МF.МКт., 1229/46, 24/Za/1335 (September 12, 1917).

32 вОА, мF.мкт., 1230/82, 28/Z / 1335 (October 16, 1917). Still in late October, the Ministry of Education was sending orders for the completion of necessary documentation: воА, MF.MKT., 1231/7, 09/M /1336 (October 26, 1917). BOA, MF.EYT., 7/ 57, 1/Ağ/1333 (October 1, 1917).

34 "Sitzung des Ausschusses für türkische Schüler und Lehrlinge der DTV, 17.Sept.1917, Berlin," Auswärtiges Amt Archives, R63063. 
[Bauernsöhne] and not "orphans from the city" [Waisenkinder aus der Stadt]. ${ }^{35}$ In the end, only about 150 agricultural apprentices arrived, in two different convoys in June and July $1918 .^{36}$ The boys were mainly sent to the north and east of the country; there were only a few in central Germany and in the Rhineland.

Each apprentice had his own identity card, on which was printed his profession, workplace, the Chamber of Trade to which they were attached and their assignment number. There was also a plan to complete the cards by taking a photograph. ${ }^{37}$ The names of the children, as recorded in documents in the German and Ottoman archives-partial lists of apprentices, correspondence regarding complaints, passports, etc.- - show that they were without exception Muslims. However, the newspaper article in Berliner Tageblatt, which also included the photo of the first group of 314 boys, wrote that the boys "come from various ethnic groups [Völkerstämme]." Relying on the photograph, the reporter even argued that "one can see both the white faces of the Armenians and Jews, Anatolian types and also Arabs and negroes among them."38

\section{Foreign Boys in Foreign Homes}

\section{Turkish Students in German Families}

Turkey is about to send a large number of Turkish students to Germany to attend German schools, including sons and daughters of the best families of the country. Naturally, it is of great importance for the future of TurkishGerman relations that these boarded pupils not only receive German education, but also find a home [eine Heimat finden] in good German families that could replace their parental home. The [selection] committee in Constantinople, made up of distinguished Germans, will act as the guarantor for hosted students. The Deutsch-Türkische Vereinigung addresses all those families who are willing and in a position to house these Turkish boys or girls hospitably from themselves and whose household offers all security also for the Turkish parents, to please notify their

35 “30. Vorstandsitzung der DTV, am 29.Oktober.1917, Berlin," Auswärtiges Amt Archives, R63064.

36 “37. Vorstandsitzung der DTV am 3.August.1918, in der Deutschenbank, Berlin," Auswärtiges Amt Archives, R63454.

37 "Türkische Jugend in Berlin."

38 Ibid. 
willingness and any wishes about the age to our office: Berlin W. 35, Schöneberger Ufer $36 a .{ }^{39}$

Based on the training contract signed by the Chambers of Trade and Industry and a representative of the Ottoman embassy, the apprentices agreed to a nonpaid three-year apprenticeship and also to work for a year as a journeyman in the same place for a journeyman's wage. In return, the master craftsmen would provide shelter, board and, in time, some clothing (excluding underwear and shoes). The DTV considered it desirable to let apprentices follow regular instruction in German, and so some attended part-time or night classes in order to improve their language skills. ${ }^{40}$ Those who completed their apprenticeships were given certificates. A few examples are preserved in the Ottoman archives, submitted by the apprentices themselves for translation and accreditation purposes. ${ }^{41}$

The DTV chose the master craftsmen after a thorough examination of their household and family structures. An apprentice was only entrusted when the DTV was convinced that the boy would be treated as a child of the house. ${ }^{42}$ In its information leaflet for German households accepting Ottoman boys,

39 Türkische Schüler in deutschen Familien. Die Türkei ist im Begriff, eine größere Anzahl türkischer Schüler und Schülerinnen zum Besuch deutscher Lehranstalten nach Deutschland zu entsenden, darunter Söhne und Töchter der besten Familien des Landes. Es ist naturgemäß für die Zukunft der deutsch-türkischen Beziehungen von großer Bedeutung, dass die Zöglinge nicht nur die deutsche Schulbildung erhalten, sondern vor allem auch in guten deutschen Familien eine Heimat finden, die ihnen das Elternhaus ersetzt. Für die Art der unterzubringenden Schüler und Schülerinnen bürgt ein Ausschuss in Konstantinopel, dem angesehene Deutsche angehören. Die Deutsch-türkische Vereinigung richtet an alle solche Familien, die bereit und in der Lage sind, junge Türken oder Türkinnen gastfreundlich bei sich aufzunehmen und deren Haushalt auch den türkischen Eltern alle Bürgschaft bietet, die Bitte, ihre Bereitwilligkeit, auch etwaige Wünsche über das Alter, der Geschäftsstelle, Berlin W. 35, Schöneberger Ufer 36a, mitteilen zu woollen (“Türkische Schüler in deutschen Familien," Tägliche Rundschau, July 3, 1916). In the future, those willing could even follow other classes (for example maths) or even attend a vocational school. Russack, "Die türkischen Lehrlinge," 62.

41 BOA, MF.M Кт., 1238/91, 05/N /1337 (June 4, 1919).

42 Already in mid-1916, the DTV had arranged more than 1,800 families to accommodate scholarship-holding Turkish pupils. "20. Vorstandsitzung der Deutsch-Türkischen Vereinigung am 15.Juli.1916 in der Nationalbank für Deutschland, Berlin,” Auswärtiges Amt Archives, R63435.

Such a great number raises doubts about the motivations and 'quality' of these families. As I will touch upon later, some critics claimed that these were usually poor soldier families, who volunteered to receive Turkish boys in order to have access to some financial means. 
the DTV underlined the program's two goals. ${ }^{43}$ First, the boys should become accustomed to German morals, ethics, honesty, thoroughness and industriousness. In order to facilitate this kind of cultural transfer, the mining apprentices, for instance, were sheltered in experienced miners' families, so that they not only worked but also lived in a mining environment in their homes. However, their religious and national character was not to be threatened: religious influence should be avoided, and the boys should be given the opportunity to perform their daily prayers and to follow Islamic religious holidays. The masters were also warned against offering them pork and alcoholic beverages, both prohibited by Islam. ${ }^{44}$ On paper, rules and responsibilities of both sides were very well-defined and compatible with standard procedures. However, the experiences on both sides were far from perfect.

\section{Insufficient Preparation, or Blue Caps and Pelerines}

The most recurrent conflict in the first months after the arrival of craft apprentices was the "insufficient preparation" [ungenügender Vorbereitung] of the Ottoman side for the transfer of the boys. German masters repeatedly complained that they provided beyond their original agreements, due to the boys' insufficient clothing. The Chambers of Trade and Industry underlined that Professor Jäckh had prepared the contract so that the boys would bring two outfits, along with underwear and shoes, so that their masters would not have any clothing costs for at least a couple of months-in other words, until the boys had become productive to compensate for their own expenses. However, the clothing they had when they first arrived "could not be poorer" [denkbar dürftig]; they had nothing to wear but blue caps and pelerines provided by the DTV. This is not hard to believe, knowing the circumstances in Istanbul orphanages. Some masters claimed that they had initially to spend around $100 \mathrm{Mk}$ to clothe their apprentices, since they were ashamed to let the boys-parts of their household - to be seen on the street with the clothes they had. ${ }^{45}$ There is evidence that the Ottoman Ministry of Education ordered an army tailor-Haim,

\footnotetext{
43 Gencer, Nationale Bildungspolitik, 278.

44 "An die Königlichen Provinzialschulkollegien, Der Minister der geistlichen und Unterrichts, Berlin, den 14. Oktober 1916," Auswärtiges Amt Archives, R63062; "Maarif Şuunu," Muallim, 15 Kanunuevvel 1332, 190-192.

"Report of Deutscher Handwerks - und Gewerbekammertag (E.V.): Unterbringung von jugendlichen Türken in deutschen Handwerksbetrieben, Hannover, 25.Juni.1917," Auswärtiges Amt Archives, R63063.
} 
son of Rafael - to produce outfits for the orphan boys to be sent to Germany. ${ }^{46}$ However, this was in mid-April and it is probable that he could not finish the task in time for the departure date.

When the 200 mining apprentices arrived, the same complaints reappeared regarding the lack of clothing items [mangelhafte Ausstattung], particularly shoes and underwear. There was a long-lasting 'shoe controversy' between the masters and the DTV on the one side, and the Ottoman representatives on the other. Apparently, many of the orphan boys arrived in Berlin without shoes, and even those who had some sort of footwear were not sufficiently protected against German winters. Several institutions and masters were forced to provide shoes for their apprentices out of their own pocket and later applied to the Foreign Office for compensation. ${ }^{47}$ The DTV in its turn demanded that all the expenditures caused by the Ottoman Ministry of Education's "clangers" [Missgriffe] should be covered by them. ${ }^{48}$

Insufficient clothing was also a very serious issue for the orphan boys: three mine apprentices from Frankleben-Necdet, Hüseyin and Süleymanapplied to the office of the DTV with the complaint that their clothes were not warm enough and that they were constantly cold. ${ }^{49}$ The apprenticeship work in the mines, coupled with uncongenial climate, actually risked some boys lives. An apprentice died at the Charité Hospital (Berlin) as a result of a lung disease, and many sick orphans were sent back. ${ }^{50}$

\section{Selection Mistakes}

The plans and preparations for the transfer of the children were so hastily made that there was frequent criticism regarding the selection of children from German masters, Chambers of Trade and the supervisors of the DTV. The masters complained of "wrong selection" [schlechte Auswahl] to express their discontent with orphan apprentices. It is obvious that the Ottoman authorities made the selection on purely numerical terms - to reach certain numbers, be

\footnotetext{
46 вОА, MF. мКт., 1225/38, 26/C/1335 (April 18, 1917).

47 "Letter from Reichsbekleidungsstelle an das Auswärtiges Amt, 27.Sept.1917," Auswärtiges Amt Archives, R 63063 .

48 "28. Vorstandsitzung der Deutsch-Türkischen Vereinigung am 26.Juni.1917 in der Deutschenbank, Berlin," Auswärtiges Amt Archives, R63063.

49 "Sitzung des Ausschusses für türkische Schüler und Lehrlinge der DTV, 17.Sept.1917, Berlin," Auswärtiges Amt Archives, R63063.

50 "Sitzung des Ausschusses für türkische Schüler und Lehrlinge der DTV, 2. August 1917, Berlin," Auswärtiges Amt Archives, R63063.
} 
it 200,300 , etc. - and that the process did not result in a group of suitable candidates with skills appropriate to the vacant positions. The DTV also claimed that the Ottomans sent essentially all who volunteered, without any detailed medical examination or testing boys' intellectual or moral qualities. The masters complained of orphans' poor health or their unsuitable agessome were too young or too weak, especially for mine work. As a result, during the first two months $25 \%$ were sent back in order to "clean up thoroughly the unsuitable elements" [den ungeeigneten Elementen gründlich aufzuräumen].51

Moreover, the selection committee in Istanbul was accused of disregarding both boys' previous training and the list of vacant apprenticeship positions prepared by the German Chamber of Trade and Industry. A large number of apprentices (about half) were in professions other than their previous training. When possible, boys were assigned to another but related trade, but if not, they had to remain at their assigned positions. Mining apprentices frequently applied to the DTV with the grievance that their previous training was something else and that they did not want to be employed in mining. That is the reason why many were unhappy at their work places and why several of them escaped and/or acted disobediently, or applied for either relocation or to return home. For instance, a mine apprentice named Mazhar and a trade apprentice named Mustafa Osman abandoned their posts in Fürstenwalde, due to discontent with their jobs. They had previously trained for two years as lathe operators, yet their present apprenticeships were not relevant to their vocational qualifications. The German Chamber of Trade and Industry unfortunately responded that currently there was no chance to accommodate them as lathe operators. ${ }^{52}$

The Chambers were also unhappy about the arrival dates and job reassignments of the boys. The starting date for German apprentices was traditionally Easter, but the transfer of the Ottoman boys to their posts was delayed until mid- or the end of May. Consequently, the change of training caused further hardship for the Chambers. ${ }^{53}$ Months after their arrival, many trade apprentices had to be accommodated in hotels in Berlin, since the authorities were considering whether they should returned home or assigned to another apprenticeship. ${ }^{54}$

$51 \quad$ Russack, "Die türkische Lehrlinge," 49.

$5^{2}$ "Sitzung des Ausschusses für türkische Schüler und Lehrlinge der DTV, 2. August 1917, Berlin," Auswärtiges Amt Archives, R63063.

53 "Report of Deutscher Handwerks- und Gewerbekammertag (E.v.): Unterbringung von jugendlichen Türken in deutschen Handwerksbetrieben, Hannover, 25.Juni.1917," Auswärtiges Amt Archives, R63063.

54 "Sitzung des Ausschusses für türkische Schüler und Lehrlinge der DTV, 20.Juli 1917, Berlin," Auswärtiges Amt Archives, R63063. 
The issue of boys making mistakes in their career choices was also a concern for the Ottoman administrators. A report by Muslihiddin Adil Bey, Director General of Secondary Education, written in the form of a travelogue following his visit to Germany in May 1333 [1917], touched upon the career choices as a problematic area. He claimed that most of the boys went to Germany without having any idea about the curriculum of their future studies. Most of them chose their trades by mere chance and others were placed in trades that were not in accordance with their skills and aspirations. Actually, very few apprentices were informed about the trade in which they would be apprenticed, the length of their training or the city or school to which they were going. ${ }^{55} \mathrm{With}$ such lack of information, it was only natural that many of them had problems with their workplaces and with the nature of work they were asked to perform.

\section{The Struggle to Belong: Difficulties of Integration}

In accordance with the demands of the Ottoman government, most of the boys were assigned to workshops in small and medium-sized towns, to facilitate their integration into a foreign society and to enable the boys to meet intermittently. In this way it would also be easier to monitor them. However, integration of Ottoman orphans remained an unaccomplished goal. As destitute and rootless lads, orphan boys were not only away from home, but, as noted at the start of this paper, also suffered from poverty, exclusion and disconnection.

Language competency was an obstacle that complicated everyday experiences. Apprentices were not offered a period of language training, so all of them arrived at their posts without any knowledge of German. Some tried to follow courses after they were settled, but the reports of the Chambers of Trade and Mining Administrations point that the progress of most of the boys was next to nothing. In order to facilitate communication between masters and apprentices a 700-word dictionary was prepared on the instruction of the Chambers of Trade. ${ }^{56}$ However, it was not at all useful for the Ottoman boys. All of the sections, explanations and words were from German to Turkish only (Figure 6.3). Moreover, it was written in the Latin alphabet, whereas these

55 Muslihiddin Adil (Taylan), Alman Hayat-ı İrfanı (İstanbul: Matbaa-ı Âmire, 1333 [1917]), 229-231.

56 "Ein kleines Wörterbuch, das wir auf Wunsch des deutschen Handwerks- und Gewerbekammertags für die Handwerkslehrlinge herausgegeben haben. 24.Juli.1917," Auswärtiges Amt Archives, R 63063. 


\section{Worte Deutsch-Türkisch}

\section{Allgemeine Redensarten.}

$$
\begin{aligned}
& \text { willkommen ...... merhaba } \\
& \text { guten } T a g \text {...... sabachynis hair } \\
& \text { olsun } \\
& \text { guten Abend ..... akschamynys } \\
& \text { gair olsun } \\
& \text { gute Nacht ...... gedschenis hair } \\
& \text { olsun }
\end{aligned}
$$

wie geht es Ihnen? kefinis ne dir? was gibt es Neues? ne war, ne jok? bitte nehmen Sie

Platz........ bujurun, efendim, oturunus

aff Wiedersehen I allaha ysmarGott befohlen J ladyk

kommen Sie gut

nach Hause ..... güle güle (gidinis)

das walte Gott ... inschallah

mein Herr ........ effendim

bitte, gefalligst.... lutfen

bitte! ........... ridscha ederim

danke sehr ....... tschok teschekkîr

haben Sie die Güte af ederssinis

macht nichts! .... sarar jok

ja $\ldots . . . \ldots \ldots$....... ewet

nein $\ldots \ldots \ldots \ldots$. hajr

$\operatorname{los} \ldots \ldots \ldots \ldots$ hajdi

*

Vtrstehen Sie mich ? aniadynysmy? sprechen Sie langsam jawasch sojlinis wie nennt man das? buna ne derler? Was bedeutet ..... ne demek...

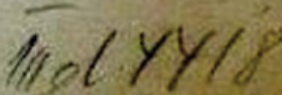

\section{Berufe, Gewerbe.}

Arbeit, die........ isch

Arbeiter, der...... amele

Arzt, der ......... hekim, tabib

Băcker, der ....... ekmekdschi

Barbier, der....... berber, perúkar

Bauer, der ....... tschiftdschi

Baugewerbe, das... kalfalyk

Bautischler, der ... marangos

Bildhauer, der.... hejkeltrasch

Böttcher, der ..... fytschydschy

Buchbinder, der ... müdschellid

Buchidrucker, der .. basmadschy

Dachdecker, der ... damdschy

Dolmetscher, der .. terdschüman

Drechsler, der..... tscharchdschyk

Eisengießer, der demir dökmekdschi

Eisenhăndler, der demir tidschary

Elektriker, der . elektrikdschi

Färber, der ...... bojadschy

Feilenhauer, der... ejedschi

Fleischer, der ..... kassab

Friseur, der...... berber

Gărtner, der ..... bagtschewan

Gerber, der....... tabbag

Geselle, der....... kalfa

Glaser, der ...... dschamdschy

Goldschmied, der . . kujumdschu

Handwerk, das.... sana-at

Handwerker, der .. sana-atkjar

Handwerkskammer, die sana-at odassy

Hauswirt, der..... ew sahibi

Hauswirtin, die ... ew sahibessi

Hufschmied, der... nalband

Kaufmann, der.... tidschar

FIGURE 6.3 Pages from the dictionary for apprentices. 
boys, if they knew any writing, only knew how to read and write in the Arabic script.

Apprentices could have learnt the language in the exact same way that they acquired knowledge and skill: by observing, imitating, practicing and interacting with experienced workers and masters. However, relations were not always smooth between Turkish apprentices and their German colleagues and masters. As a pilot integration project, the apprentices in the ore mines of the Harz Goslar in Eisleben co-habited with the Germans. The administration assumed this would facilitate the linguistic progress and mutual interaction of the boys. Instead, there were serious problems and difficulties, from verbal harassment to physical disturbance and fights. Later, the boys were separated during work hours and accommodated in separate wards. ${ }^{57}$

The other everyday discontent was food. Many boys acknowledged that the bread was much better in German homes and workplaces, but they were never sure whether or not the meals contained pork. They were constantly served dark colored soups with unfamiliar tastes. ${ }^{58}$ In other cases, the boys complained that they were provided with only one meal and nothing else to eat. ${ }^{59}$ Four mine apprentices from Altenberg and Eschbach escaped, complaining that the food was bad. ${ }^{60}$

Critics of the project argued that Turkish students were usually settled with poor soldier families, in order to make sure that these people were provided with some means of assistance. Student boys' pocket-money (either sent by their guardians or state scholarships) became family income, since the residents paid for food and board. When the boys complained, as they frequently did, of the scarcity and/or distastefulness of the food, they were told in a hostile manner "to write to home for better food,"61 or else, when they applied to

\section{Russack, "Die türkische Lehrlinge," 59-6o.}

$5^{8}$ Although Muammer Tuksavul was in the relatively rich student group and had enough funds to stay in pensions, he was unable to eat the soup served by his host. Muammer Tuksavul, Eine bittere Freundschaft: Erinnerung eines türkischen Jahrhundertzeugen (Düsseldorf: Econ Verlag, 1985), 162-163.

59 "Sitzung des Ausschusses für türkische Schüler und Lehrlinge der DTV, 20. Juli 1917, Berlin," Auswärtiges Amt Archives, R63063.

6o "Sitzung des Ausschusses für türkische Schüler und Lehrlinge der DTV, 2. August 1917, Berlin," Auswärtiges Amt Archives, R63063.

61 There is actually evidence for the transfer of food from the Ottoman Empire to Germany for students. The DTV arranged with Ismail Hakkı Paşa, the undersecretary of the War Ministry at the Embassy (Generalintendant der Armee or Harbiye Nezareti Müsteşarı), the procurement of $120 \mathrm{~kg}$ rice, 100 of beans, $200 \mathrm{~kg}$ raisins and $32 \mathrm{~kg}$ oil (and paid for them) in October 1917, although their arrival was delayed until February 1918, due to 
the DTV, they were threatened with being sent back and made into soldiers. ${ }^{62}$ German school directors, pension holders and craft masters were in a difficult position with the food costs of the boys. They claimed that catering for the boys' preferences under war conditions was extremely costly: they consumed rice, mutton, a lot of bread, and sugar and other things which could be procured only with great difficulty. Moreover, they did not eat pork and refused sausage, which were cheaper and easier to provide. ${ }^{63}$

\section{Resistance, Revolt and Escape as Empowerment}

Accounts of boys running away and other such stories have been documented only sporadically. However, we know for certain that by November 1918, there were only 140 mine apprentices left in Germany out of the 200 initially sent, and only 181 trade apprentices from the $314 ;{ }^{64}$ almost $40 \%$ of the boys were either unsuitable for the designated project or dissatisfied and discontented. This was a paradise lost: the Ottoman boys had dreamed of a better training environment with more opportunities; and they were hoping to earn some money, and perhaps get rich, and benefit from the promises of European prosperity. When these dreams were shattered in the face of their living and working conditions, the orphans started to resist, even revolt.

The Chamber of Trade and Industry was worried that only a few masters gave positive feedback of well-behaved and modest apprentices, who fit well into German standards. Many masters resented having agreed to have Ottoman boys, who were demanding monetary compensation and free time. Both were considered incompatible with the rights and responsibilities of an apprentice in Germany. ${ }^{65}$ The boys were supposedly acting very arrogantly and

lengthy negotiations. The DTV also attempted to arrange with the Ottoman Ministry of Education the sending of food stuffs on regular intervals. "Lebensmitteln für die türkischer Schüler in Deutschland, From Kaiserlich Deutsche Botschaft, Pera, 19.Juli.1918," Auswärtiges Amt Archives, R63065.

62 "Was ein aus Deutschland kommender Reisender erzählt, Akşam, 5.Dez.1918 [Übersetzung, Gabel]," Auswärtiges Amt Archives, R63066.

63 "From Königliches Provinzialschulkollegium der Provinz Hannover, 25.mai.1917," Auswärtiges Amt Archives, R63063. However, some masters reported that most of them did not abstain from eating pork. Gencer, Nationale Bildungspolitik, 278.

64 “Jahresbericht des Schülerheims, 1.Nov.1918," Auswärtiges Amt Archives, R 63065.

65 "Report of Deutscher Handwerks- und Gewerbekammertag (E.v.): Unterbringung von jugendlichen Türken in deutschen Handwerksbetrieben, Hannover, 25.Juni.1917," Auswärtiges Amt Archives, R63063. 
self-confident. They insisted that they were promised, so entitled to, employment in a factory and a handsome monthly salary. ${ }^{66}$ No matter how futile it was, orphan boys kept asking for time and money to remedy their situation, for self-determination, and possibly to move elsewhere.

The main problem was the children's misinformation, or mis-imagination. Most of the boys came assuming that they would be settled in with trade masters, in accordance with their previous training. They had no idea that they would end up in mine work. In the coal mines of Breslau, the boys were openly resistant. They were rude towards their co-workers and they frequently refused to perform the tasks that they were ordered to do. The boys said they were being exploited with repetitive tasks and very hard work and they quit the work premises; ${ }^{67}$ this is perfectly understandable given the difficulties of coal mining. Four mine apprentices from Altenberg and Eschbach escaped because they had no pocket money and they were treated badly. ${ }^{68}$ Orphan boys in the Rammelsberg mine administration were reported for evading their duties and they clearly had no interest in the work operation. ${ }^{69}$ Apprentices, on the other hand, were rightfully complaining that they were not learning anything, apart from transporting stones. ${ }^{70}$

There was even a small uprising in the Royal Oberharzer mining and metallurgical works [Oberharzer Berg- und Hüttenwerke]. Fourteen Ottoman boys, supposedly under the leadership of a certain "negro Mehmed Tevfik," refused to perform their tasks and disturbed work discipline. Mehmed Tevfik was accused of discouraging his countrymen from work with "threats and illtreatment" [Drohungen und Misshandlungen $] \cdot{ }^{71}$ However, what turned minor cases of resistance into open revolt was the employment of several boys in the same work place. Group feeling strengthened the boys and encouraged them to take action. A common form of collective resistance was to escape to urban centers and allegedly get involved with the various 'vices of the cities.' For instance, eight out of the total 10 apprentices in Royal Mining Inspection Rüdersdorf escaped the mines shortly after their arrival and did not come back. A few weeks later, five of those eight escapees were found at Friedrichstraße

\footnotetext{
$66 \quad$ Ibid.

67 Russack, "Die türkische Lehrlinge," 59.

68 "Sitzung des Ausschusses für türkische Schüler und Lehrlinge der DTV, 2. August 1917, Berlin," Auswärtiges Amt Archives, R63063.

69 Russack, "Die türkische Lehrlinge," 60.

70 "Sitzung des Ausschusses für türkische Schüler und Lehrlinge der DTV, 17.Sept.1917, Berlin," Auswärtiges Amt Archives, R63063.

71 "Sitzung des Ausschusses für türkische Schüler und Lehrlinge der DTV, 20.Juli 1917, Berlin," Auswärtiges Amt Archives, R63063.
} 
train station and were sent back to their posts at Rüdersdorf by the DTV. However, the whereabouts of other three remained unknown. ${ }^{72}$

Typical 'problem boys', as in the case of Raif Efendi in Sabahattin Ali's novel, ended up frequenting the night life and committing petty crimes. This issue was more common among vocational students, who were financially supported by their parents and so had access to money. A certain Sinai Cemal was quite adventurous in this respect. As the report of Consul Elfeld from Bremen describes it, he was first registered to a school in Bremen, where he was involved with several criminal acts: he embezzled the boarding-house money that was entrusted to him; he instilled an "oriental vice" [ein orientalisches Laster], probably hashish, in another Ottoman classmate; and he was accused of a shop theft that he committed with other classmates. Due to these charges Sinai Cemal was sent to a smaller provincial town, Göttingen, in the hope that there he would find fewer occasions to lead such a "dissolute lifestyle" [liederlichen Lebenswandel]. However, he could not be stopped. His landlady, Mrs Giercke-also the mother-in-law of Consul Redemann from Göttingen - reported that Sinai Cemal had damaged property within and outside the house several times and had also procured money from Mrs Giercke by lying to her that he needed the amount for his tailor's bill. Moreover, he was constantly hanging around late at night in bars in the company of a few other Ottoman classmates. His landlady also claimed that he had contracted a sexually transmitted disease. Later, Sinai disappeared from Göttingen to go to Berlin and left behind a total debt of $600 \mathrm{Mk}$. The DTV decided to delete Sinai Cemal from the student list and pay off his debts. He would be sent back by the Ottoman Embassy, as soon as his location was determined. ${ }^{73}$

$72 \quad$ Ibid.

73 "Sitzung des Ausschusses für türkische Schüler und Lehrlinge der DTV, 2. August 1917, Berlin," Auswärtiges Amt Archives, R63063.

Another such case was that of Hasan Refet Sadrettin. Immediately upon his arrival in Berlin, he was placed with the family of Professor Fries (Grunewald, Kunostr 58 ). On the evening of September 1, 1916, he left the house on the pretext that he had to bring some Turks from the station. He actually did that, but afterwards did not return home, but rather spent the night in the company of a 'lady' in Hotel Saxonia, where he introduced himself as a 'prince' (he even had business cards as "Prince H. Refed Sadreddin"), and disappeared the next morning, without paying his bill. When the hotel contacted the DTV, the whole affair became known. He was emphatically warned that he would be sent back to Istanbul directly in the case of a similar fault. Unfortunately, his behavior did not change the least and his landlord found out that he spent another night with another 'lady' in Hasenheide. When Professor Fries spoke to him once more, he admitted that he used to live like that in Istanbul as well. It was also discovered that he had borrowed large amounts of money from the house's maidservant, from another boarder, Sudfaddin 
As such cases multiplied, criticism appeared on the Ottoman side regarding the success of the project of sending students and apprentices to Germany. After visiting German educational institutions in Berlin, Leipzig, Heidelberg, Munich, Dresden and Chemnitz, Muslihiddin Adil Bey concluded that the education of Ottoman youths in Germany, or in other Western countries, was a serious national problem. ${ }^{74} \mathrm{He}$ criticized the fact that most of the boys were of secondary school age: this was the ideal time to teach the history and traditions of a country, together with the fundamentals of the native language, but boys who did not have enough knowledge about their own national history and language could not "represent Turkishness and the country's national ideals in the future." He argued that student exchange programs should not involve teenage boys. Sending high school graduates to improve and expand their professional knowledge would be of more value.

Adil Bey also underlined the need to constantly supervize these young boys, due to the endless possibilities (and vices) of night life in European cities. He wrote that the danger of these inexperienced boys falling into crime and debauchery was his biggest fear and concern. ${ }^{75}$ Similar criticisms appeared elsewhere: an article was published in the Ottoman daily Akşam [Evening], based on the observations of a traveler from Germany. He explained that many coffee houses were filled with Ottoman students who hung around as vagrants [Landstreiche] in a depraved state [verwahrlost]. Sadly, he said, many of them did not even learn the German language. ${ }^{76}$ Due to prolonged residence in "places of terrible debauchery" [Stätten der fürchterlichsten Liederlichkeit], such as Berlin, many got accustomed to the vulgarities [Gemeinheiten] of this life, many contracted sexually transmitted diseases and some became completely Germanized. The author also assured his readers that the issue of students and apprentices was "the biggest villainy that Germany inflicted upon [the Ottoman Empire] during this war."

The source material for this research, in the form of DTV reports (either prepared by local administrators or central supervisors) and the Ottoman archives, is thoroughly biased in terms of putting all the blame on the youth, depicted as

Kemal, and from Professor Fries himself. As a consequence, he was deleted from the student list of the DTV and school principals, parents, the Board of the Student Committee of Istanbul and the Ottoman Embassy were informed. "Bericht über Hasan Refet Sadreddin," Auswärtiges Amt Archives, R63062.

74 Adil (Taylan), Alman Hayat-ı Irfanı, 229-233.

75 Ibid.

76 "Was ein aus Deutschland kommender Reisender erzählt, Akşam, 5.Dez.1918 [Übersetzung, Gabel]," Auswärtiges Amt Archives, R63066. 
either ill-prepared for the nature of their training, or not accustomed to work discipline, or rude, or a bad influence on each other, etc. The disobedience of the boys was regarded with an even 'colonial gaze. ${ }^{77}$ Dr Russack argued that the difficulty teaching regular work, discipline and obedience stemmed from the boys' untamed nature. They were "children of nature" [Naturkinder] lacking the basic formation of civilized manners to adapt to German standards of hard work. ${ }^{78}$

Social historians, informed by post-colonial theoretical frames, underline the difficulty of hearing the voices of the subaltern, especially in sources. The solution is to read the documents against the grain. In this section, in order to strengthen the volume and depth of the children's side of the story, I focused on the perspectives of the boys themselves, based on the complaints they made and several escape stories. With some sympathy for them and some attention on their lives, it is not so hard to reconfigure the narrative from children's eyes. They were not simply lazy, disobedient or problematic for no reason. They were deeply disillusioned with the opportunities they were offered in Germany. Most of them were not offered proper vocational training, and their hopes of leading more prosperous lives were shattered. What the authorities saw as 'going out of the way' was both related to their young age and the opportunities of freedom and night life. More importantly, they were to trying to compensate for their disappointments relating to the ad hoc and ill-prepared organization for their stay and education in Germany.

\section{Home Sweet Home}

The pressure and necessities of the war facilitated rather than impeded the policy of child displacement between the two empires. The project was initiated in the middle of the war (1916), and it practically came to an end with the end of the war. The defeat of the Central Powers not only challenged the future of the German and Ottoman empires, but also made the continuation of educational collaboration projects impossible due to financial difficulties and organizational impossibilities. In the spring of 1919, the DTV informed the masters and mine authorities that Ottoman orphans were supposed to return by steamers departing from Hamburg. Three steamers, the Akdeniz, the Reşid

\footnotetext{
77 As we learn from many works on the 'colonial gaze,' it was not rare for 'civilized' Westerners to see the less developed colonies as 'barbarians,' 'savages,' or as 'untamed' (animals). Pramod K. Nayar, Colonial Voices: The Discourses of Empire (Malden, MA: Wiley, 2012).

78 Russack, "Die türkischen Lehrlinge," 61.
} 
Paşa and the Gülcemal, departed in May, June and August 1919, carrying Ottoman soldiers, officials and students.

We, the Turkish students, do not want to miss this moment, as we leave German soil, to express our deepest gratitude for the hospitality and helpfulness that we were granted here at all costs.

We are well aware that we owe much to German culture, which helped us become competent.

We are happy to have spent our best years in this glorious land and we will always remember it with heartfelt pleasure. ${ }^{79}$

These were the farewell words of a student, shortly before the departure of the Gülcemal. His speech, together with that of Zeki Paşa, underlined "the sincere helpfulness of Germany towards Turkey" and expressed the importance with which the Ottomans regarded German culture and German hospitality. Despite numerous crises, regrets and disappointments on all sides, in the concluding phase of the project, official declarations tended to emphasize gains and accomplishments. Ottoman orphan boys were definitely not of the same opinion.

Most of the orphan apprentices were loaded onto the Akdeniz in May 1919 and arrived in Istanbul in the same needy circumstances in which they had left the city. The most serious problem was to lodge these destitute boys, since the former abodes of many were no longer functioning. With the Allies occupying the country, confiscated buildings were repossessed by their rightful owners, ${ }^{80}$ meaning that most state orphanages had to be closed: their buildings were no longer under government control and the government was unable to offer alternative buildings. Sixty-one orphanages in Anatolia were closed and only a few continued to operate in Istanbul. About 3,500 orphans in these institutions lived in very poor conditions, without basic alimentation or adequate clothing. ${ }^{81}$

The orphan boys who came back from Germany could not fit easily into these already downsized and crowded orphanages. Almost of the orphans who came back from Germany were put into Yedikule Orphanage, due to its closeness to state factories; ${ }^{82}$ most of the returnees were employed in Zeytinburnu Iron Factory [Zeytinburnu Fabrika-i Hümayunu]. A younger inmate of the same orphanage complained in his memoirs that these older boys had no

79 "Dank türkischer Untertanen an Deutschland," Hamburger Fremdenblattes, 113, August 9, 1919.

8o Abdurrahman Şeref recounts that the French Fathers themselves evicted the orphans from the Kadıköy orphanage, their Collège de Saint Joseph. твмм zс, 465.

81 Dinamo, Öksüz Musa, 13-30; твмм zC, 452-453, 458-459.

82 BOA, DH.UMVM., 119/15, 16/N/1337 (June 15, 1917). 
proper education and that they talked, made naughty jokes and laughed all night. ${ }^{83}$ Boys who had been brought from orphanages in Anatolia were in especially difficult circumstances: their orphanages were closed and they were great distances away from their hometowns, with no means or assistance for getting there. Some were 'temporarily' sheltered in the Poorhouse [Darülaceze], in various hospitals or in existing orphanages. However, this supposedly limited residence lasted longer than expected, and they were not sent back until March 1922. ${ }^{84}$

Squeezed between Ottoman demands for quantity and German demands for quality, orphan boys were expected to accomplish an impossible mission. Orphans themselves felt betrayed in two fronts. As noted above, their hopes of leading more prosperous lives in Germany had been shattered; but they were not welcomed back in their own country as qualified workers to help rejuvenate the economy, either. They were still being treated as needy orphans that the state had a hard time providing for. Despite the distances travelled and all the hardships they encountered, they were unable to remedy their circumstances as destitute children.

\section{Happy Endings}

Ahmed Talib was born in Istanbul in 1901. His mother passed away when he was three years old. His father was married again after a short time, but Ahmed was not at all satisfied with this and he constantly complained to his brother about the stepmother. Before the war years, the family's economic standing was not bad. The father had a shoeshine shop in Kadıköy and he was also an ice dealer [sellac]. The fate of the family changed dramatically with the explosion of the First World War: his father was drafted in late 1914 and killed the following year at Gallipoli. As an 'orphan of a martyr', Ahmed Talib had the privilege granted by the Ministry of Education to be admitted to the state orphanage [Darüleytam] in Kadıköy, which occupied the former premises of the famous French college of Saint Joseph. ${ }^{85}$

83 Dinamo, Öksüz Musa, 37-38.

84 BOA, DH.UMVM., 119/26, 12/B /1340 (March 11, 1922).

85 The orphans of the martyrs were a privileged group of destitute children. They were the only ones to be granted such special rights as admittance into certain civil and military boarding schools, vocational schools and the newly introduced state orphanages [Darüleytam]. 
In this over-populous boys' orphanage with about a thousand boys, he was registered to the trades department and started training in shoemaking. When he heard in early 1917 that a large number of volunteer boys would be sent by the Orphanage Administration to Germany for further training, he applied immediately. At 16 years old, Ahmed was among the first group of $314 \mathrm{craft}$ apprentices who arrived in Berlin in late April 1917. He was first transferred with 17 others to Frankfurt an der Oder, and then with four other boys to Fürstenwalde. He was settled in the household of Albert Pöthke as an apprentice cobbler as of May 1, 1917. Ahmed worked and lived in his master Albert Pöthke's house with three other German apprentices. He also attended night school to learn German. He learned fast and his training in general was very successful. They had an exemplary master-apprentice relationship: Ahmed passed the 'journeyman exam' [Gesellenprüfung] in shoemaking on April 30, 1921 with the grade 'very good' and worked at Pöthke's shop until February 10, 1923. He worked in different workplaces and factories in Berlin until he opened his own shop in Fürstenwalde in late 1927. He also married a young German woman and became a father. In 1935, Ahmed Talib was himself certified as a master by the Chamber of Trade in Frankfurt an der Oder and started to have apprentices of his own. He was well-integrated in this little town due to his German wife and total competence in the language, and by being a completely local figure in his neighborhood. It is fair to say that all his success and happiness resulted from his decision to come to Germany for training. He lived there till the end of his life and witnessed several historical eras: the Deutsches Kaiserreich, the Weimar Republic, the Third Reich and the German Democratic Republic. He was one of the very few successful boys who won his struggle to belong.

İshak Muammer was from a high-class and well-integrated family. ${ }^{86} \mathrm{His}$ father, Mehmed Cemaleddin, was the former judge [ kad l] of Mecca, Cairo and, later, Istanbul. However, his father died during the war and the family faced financial difficulties, though probably much less than the average. One of their neighbors, a certain Frau Stange, talked to him about the DTV and about the students who were being sent to Germany. When he showed an interest, she arranged a meeting with Dr Jäckh himself at Pera Palas, the famous Europeanstyle hotel in Istanbul. Later, he successfully took an exam at the DTV offices,

86 This section is prepared based on the autobiography of İshak Muammer himself: Tuksavul, Eine bittere Freundschaft. 
and in accordance with the general scholarship rules, the DTV pledged to cover his study costs and the train ride to Germany. He needed to provide for his accommodation, boarding and pocket money himself. While trying to get the necessary permission from the Ministry of Education, he benefited greatly from his father's network, such that he could see in person both Dr Nazım, who was in charge of DTV operations in Istanbul, and Şükrü Bey, the minister himself.

İshak was put on the Balkanzug, which travelled from Istanbul to Berlin only in two days and three nights, and he arrived at the end of November $1917 .^{87}$ As one of the privileged boys, this was much faster than the 10-day journey of the orphan apprentices. After he arrived, he was taken to the DTV's student home [Schülerheim] in Grunewald. ${ }^{88}$ The next day he met the director of the home and one of the key figures of the DTV, Dr Ryll. He stayed there for two nights and then went to Mannheim for his secondary school [Oberrealschule] study. His financial resources helped him to stay in a few different pensions in Mannheim. In school, his biggest problem initially was the language, but he soon proved successful in all his classes, including German. However, he found himself quite isolated in the city of Mannheim, where there were no other Turks or Muslims.

A few months before his Abitur exam in the spring of 1919, the Ottoman Honorary Consul in Mannheim, also the director of the Rheinischen Kreditbank, called him to tell that Ottoman citizens were supposed to return by steamships departing from Hamburg. However, as he was paying his own way he was not made to leave. After he got his Abitur diploma, he started to work as a trainee in the Rheinischen Kreditbank in Mannheim for two years to save money for further studies. Later, he attended the commercial college [Handelshochschule] in Mannheim and got his Abschluss in 1925. In spring 1925, he started studying chemistry in Darmstadt and Karlsruhe. During these years, he also got married a German woman. In the second half of the decade, he experienced the emergence and rise of National Socialism and felt threatened by the phenomenon. As a result, he decided to return to Turkey in 1929.

87 Before the war, the Orient Express ran between Istanbul and Paris. After the division of Europe into Entente and Central Powers, the Balkanzug passed through Sofia, Belgrade, Budapest and Oderberg.

88 The Schülerheim was opened in October 1917 in Grunewald (Herthastrasse 6) for Turkish students to spend a few days after they arrived in Berlin. They would stay there before they would go to their posts in other cities. Dr. Gerhard Ryll, "Die türkische Schülerheim in Berlin Grunewald," in Türkische Jugend in Deutschland: Jahresbericht der Schülerabteilung der Deutsch-Türkischen Vereinigung (Berlin: Deutsch-Türkische Vereinigung e.V., 1918), 42-46. 
As a businessman in the 1940s, he rebuilt his relations to Germany and kept visiting the country. Remarkably, he wrote his autobiography in German.

\section{Conclusion}

The activities of the DTV in the field of education and its collaboration with the Young Turk regime have been interpreted from an economic perspective. Gencer argues that in sending students and trainees to Germany for vocational training, the Young Turks were hoping to train pioneers for a national bourgeoisie, who would play key roles in creating a national economic policy and, thus, secure economic independence from Europe. ${ }^{89}$ Those who analyze the German side of the picture also underline how German business circles and journalists, among which Ernst Jäckh and his DTV were the most prominent, wasted no time in forging ambitious plans for the "economic development of the Sultan's lands." ${ }^{90}$ German trade masters and mining authorities also agreed to take in Ottoman orphans as apprentices for economic reasons, hoping that these children would be silent, obedient and hardworking laborers. The prospect of non-unionized and immigrant workers definitely seemed plausible, while the fear of a worker revolution was still on the air. Yet, economic explanations appear uncertain when we approach the issue from the perspective of the transferred boys.

The Ottoman administration did not have a long-term economic vision or plan. They were more interested in solving a current (and pressing) problem than in investing for a better future. The simple reason behind the desire to send as many as 10,000 orphans to Germany was the difficulty of sheltering, feeding and educating so many orphaned children and youths. Based on hastily made plans and preparations for the transfer of children (who lacked clothing, equipment, etc.), and with no regard for who was selected (former vocation, health, work ethics, etc.), we can safely argue that the only concern of the Ottoman government was the quantity they sent. The state wanted to get rid of as many lads as possible, regardless of the opportunities offered to them. Moreover, the boys were sent without a return date having been decided. The way the untimely arrived returnees were treated implies that they were not really expected to come back, at least not in the near future.

\footnotetext{
89 Gencer, Nationale Bildungspolitik, 265.

9o Ulrich Trumpener, Germany and the Ottoman Empire, 1914-1918 (Princeton, NJ: Princeton University Press, 1968), 319.
} 
The quality-either of the boys or of the training they were offered-was not even an issue for the Young Turk regime. There is even evidence to the contrary: the Ottoman Ministry of Education acted as if the German educational outlets were banishment centers for unsatisfactory students, together with burdensome orphans. In October 1917, the Ministry ruled that those who failed to pass their final exams more than once and those who did not have any chance of graduation would be sent to Germany to be trained as apprentices in crafts and agriculture. ${ }^{91}$

Why the Ottoman government was not able to 'utilize' such a large labor force at home can be understood only with a closer look at the 'foster care' mechanism. Apprenticeship is traditionally an indispensable part of household economy. It means the extension of the family model of social hierarchy and organization to extra-familial members of the household. It was practiced to redistribute underutilized labor from families to households needing more hands. Since food and clothing consumed the majority of family resources, giving away a child into the care of others brought about serious financial relief. It was not rare that public authorities bonded out orphans and indigent children as a means of public relief. ${ }^{92}$ Orphans in the Ottoman Empire were in exactly the same situation. The state was in a very weak organizational situation, financial crisis was very deep, and economic production during war years (both agriculture and industry) was very low. Therefore, the government was unable to turn this army of boys into a real workforce.

The DTV and German foreign policy makers, on the other hand, accepted the heavy burden of educating and feeding Ottoman orphans only because of the promise that they would receive "the sons and daughters of the best families of the country."93 Since there were only a few German-educated Ottomans, educating the children in Germany was a great opportunity to create a new generation, who would be "friends of Germany."94 In that respect, Germany's semicolonial educational aspirations gave the country a long-term vision, which was dependent on the quality of the minds they received. ${ }^{95}$ Dr Ryll, the inspector of the DTV for the Ottoman youths in

\footnotetext{
91 BOA, MF.M Кт., 1230/54, 20/Z/1335 (October 8, 1917).

92 Hugh D. Hindman (ed.), The World of Child Labor: An Historical and Regional Survey (New York: M. E. Sharpe, 2009), 533.

93 "Türkische Schüler."

94 "An die Königlichen Provinzialschulkollegien, Der Minister der geistlichen und Unterrichts, Berlin, den 14. Oktober 1916," Auswärtiges Amt Archives, R63062.

95 For further information on the concept of 'semicolonial mentality', see Fuhrmann, "Germany's Adventures."
} 
Germany, described the issue in a report entitled "Quantity or Quality?" (July 1918), in the following words:

The evidence is growing more and more from supporters of our work and experts-both from the Turkish and German sides-that our success does not depend on whether the number of Turkish youths studying in Germany is increasing every year by several hundreds. It depends more on the arrival of "the best minds of Turkish schools" (as it says in our guidelines), and on educating and training in our country those who could alone be the bearers of a better Turkish future. Thereby one might at first think of the "best families," i.e. the social elite of Turkish society, which has previously played the leading political role and which is also likely to continue to play that role for the time being. ${ }^{96}$

The discrepancy between what the Ottoman authorities wanted and what the German side expected of them resulted to a triangle of regrets. There was an essential difference between the two sides in defining these children. For the Ottoman side, they were simply a burden, an excessive population and disposable state property. For the German side they were potential transmitters of the German language, culture and work ethic. The only concern of the Young Turk government was the quantity, to send as many lads as possible, regardless of the opportunities offered to them. Germans, on the other hand, imagined they would receive a high quality group of boys, both to reinforce their weakening workforce and to open a new channel for social and cultural influence and supremacy over the Ottoman Empire.

Although both governments failed to get what they imagined, the sending of Ottoman children and youths to Germany to be trained and employed in handicrafts, mines and farms might well be considered background for the continuation of the sending of youth to Germany during the first decades of

$96 \quad$ "Immer mehr wächst bei Freunden und Kennern unserer Arbeit—und zwar ebenso auf türkischer wie auf deutscher Seite-die Erkenntnisse, dass ihr Erfolg nicht davon abhängt, ob die Zahl der in Deutschland studierenden jungen Leute sich alljährlich um einige Hundert vermehrt, dass es viel mehr darauf ankommt, die 'besten Köpfe der türkischen Schulen' (wie es in unseren Leitsätzen heisst) auszusondern und sie, die allein die Träger einer besseren türkischen Zukunft sein können, in unserem Lande zu bilden und zu erziehen. Dabei mag man zunächst ruhig an die 'besten Familien' d.h. an die soziale Oberschicht der türkischen Gesellschaft denken, die bisher die politisch führende Rolle gespielt hat und vorläufig auch wohl weiter spielen wird." (Dr. Ryll, "Quantität oder Qualität?: Kritische Bemerkungen zur dritten Schülerentsendung, 31. Juli 1918,” Auswärtiges Amt Archives, R63065). 
Republican Turkey. It might even be linked to the recruitment of Turkish 'guest workers' in Germany from the 196os onwards.

\section{Bibliography}

\section{Primary}

Adil (Taylan), Muslihiddin, Alman Hayat-ı İrfanı, İstanbul: Matbaa-ı Âmire, 1333 [1917].

Dinamo, Hasan İzzettin, Öksüz Musa, Istanbul: Heyamola Yayınlanı, 2005.

Fünfzig offizielle Gäste, "Die Studienreise der osmanischen Delegation - ein Meilenstein in den deutsch-türkischen Beziehungen.” In Ingeborg Böer, Ruth Haerkötter and Petra Kappert (eds), Türken in Berlin 1871-1945: eine Metropole in den Erinnerungen osmanischer und türkischer Zeitungen Berlin: de Gruyter, 2002, 107-116.

Grand National Assembly, Minutes of the 2nd Parliament, 1st Legislative Year (August 11, 1923-February 28, 1924), 15th Session (September 8, 1398 [1923]), 448479. Available online: http://www.tbmm.gov.tr/tutanaklar/TUTANAK/TBMM/do2/ c001/tbmmo2001015.pdf.

"Maarif Şuunu," Muallim, 15 Kanunuevvel 1332 [28 December 1916], 190-192.

Russack, Hans Hermann, "Die türkische Lehrlinge," in Türkische Jugend in Deutschland: Jahresbericht der Schülerabteilung der Deutsch-Türkischen Vereinigung, Berlin: Deutsch-Türkische Vereinigung e.V., 1918, 47-65.

Ryll, Gerhard, "Die türkische Schülerheim in Berlin Grunewald," in Türkische Jugend in Deutschland:Jahresbericht der Schülerabteilung der Deutsch-Türkischen Vereinigung,

Berlin, Deutsch-Türkische Vereinigung e.V., 1918, 42-46.

Tuksavul, Muammer Eine bittere Freundschaft: Erinnerung eines türkischen Jahrhundertzeugen, Düsseldorf: Econ Verlag, 1985 .

"Türkische Jugend in Berlin," Berliner Tageblatt, 216, May 6, 1917.

“Türkische Schüler in deutschen Familien," Tägliche Rundschau, July 3, 1916.

\section{Secondary}

Aytekin, Hakan, "1914-1924 Yllları arasında Korunmaya Muhtaç Çocuklar ve Eğitimleri, Marmara Üniversitesi, Türkiyat Enstitüsü," unpublished MA Thesis, 2006.

Benezra, Nissim M., Une Enfance Juive à Istanbul, 19n-1929. Istanbul: Isis, 1996.

Fortna, Benjamin C., "The Kindergarten in the Ottoman Empire and the Turkish Republic," in Roberta Lyn Wollons (ed.) Kindergartens and Cultures: The Global Diffusion of an Idea, New Haven: Yale University Press, 2000, 251-273.

Fuhrmann, Malte, "Germany's Adventures in the Orient: A History of Ambivalent Semicolonial Entanglements," in Max Langbehn Volker and Mohammad Salama (eds), German Colonialism: Race, the Holocaust, and Postwar Germany, New York: Columbia University Press, 2011, 123-145. 
Gencer, Mustafa, BildungspolitikNationale, Modernisierung und kulturelle Interaktion: Deutsch-türkische Beziehungen (19o8-1918), Münster: LiT, 2002.

Hindman, Hugh D. (ed.), The World of Child Labor: An Historical and Regional Survey, New York: M. E. Sharpe, 2009.

Kıranlar, Safiye and Aynur Soydan Erdemir, "Köyün Modernleştirilmesine Dair Bir Uygulama ve Proje: Kimsesiz Köy Çocuklarının Köyde Eğitimi,” Yakın Dönem Türkiye Araştırmaları, 8, 2005, 94-113.

Maksudyan, Nazan, "Children and Youth (Ottoman Empire)," in Ute Daniel, Peter Gatrell, Oliver Janz, Heather Jones, Jennifer Keene, Alan Kramer and Bill Nasson (eds), 1914-1918-online: International Encyclopedia of the First World War, Berlin: Freie Universität Berlin, 2015, http://dx.doi.org/10.15463/ie1418.10595.

Nayar, Pramod K., Colonial Voices: The Discourses of Empire, Malden, MA: Wiley, 2012.

Şafak, Nurdan, "Darüleytam'da Çocuk Olmak: On Çocuk On Portre," FSM İlmi Araştırmalar Insan ve Toplum Bilimleri Dergisi, 2, 2013, 261-284.

Trumpener, Ulrich, Germany and the Ottoman Empire, 1914-1918, Princeton, NJ: Princeton University Press, 1968. 